\title{
Obligation to Resign Legislative Members in Regional Election: Is There Unequal Treatment?
}

\author{
Zaka Firma Aditya ${ }^{1}$, Abdul Basid Fuadi $^{2}$ and Rizkisyabana Yulistyaputri ${ }^{3}$ \\ \{zaka.firma@mkri.id ${ }^{1}$, abdul.basid@mkri.id², rizkisyaban@ mkri.id ${ }^{3}$ \} \\ Center for Research and Case Analysis, The Constitutional Court of the Republic of Indonesia ${ }^{123}$
}

\begin{abstract}
This article discusses the obligation resignation of members of the House of Representative/district (DPR/DPRD) when it will run into the head region. As a political position, DPR/DPRD members who run for Regional Heads required to resign first as mandated by the Constitutional Court Decision Number 57/PUU-XI/2013. It is considered as a form of injustice because the minister and incumbent as a political position are not required to resign. Even though the minister or incumbent's potential for abuse of power is enormous but only needed to take leave during the campaign. Besides, in practice, the abuse of the region head's authority often found the use of positions to mobilize employees in the regions. Members of the DPR/DPRD do not own this authority because they have no mass base and areas. Some of the questions that will answer in this article are. (1) whether there has been unequal treatment in this matter? (2) what are the constitutional Court considerations in determining the legal politics of this matter? and (3) Is the obligation to resign members of the DPR/DPRD still following the development of the political system in Indonesia?
\end{abstract}

Keywords: obligation; resign; election; legislative member; unequal treatment

\section{Introduction}

The Direct Regional Head Election in Indonesia is a framework of the institution to create a democratic process in every region [1]. This process expected to make an area become one of the pillars of the welfare's community, both from an economic and political perspective. On the other hand, the Direct Regional Head Election can also expect to deliver a region head full of the integrity and accountability for their people [2]. Therefore, both of them will have a sense of belonging, which will allow many parties to get involved in the local government's policymaking. In the other word, the people's potential is to get involved in the local election or the seats in parliament and the active involvement of the people broadly [3].

Direct Regional Head Election can be a significant political breakthrough and have enough implications for the district and the people to create a local democratization area. For those reasons, it is a process to strengthening and deepening the democracy and efforts to achieve good, clean and effective governance. The direct regional head election is the sovereignty of the people as a realization of the principles of democracy which includes guarantees of the principles of individual freedom and equality, especially in political rights [4]. Deepening democracy, like Reuschmeyer had said (1992), it is an effort to overcome the weakness of substantive democratic practices, especially to respond to the demands of local people [4]. 
Regional Head Election linked with two main principles ie a democratic principle and the rule of law principle. The democratic principle is so essential because the Regional Head Election is a form of democracy. It must include the democratic principle and the value of democracy in this implementation. The rule of law principles will give some guaranties for the human rights inside [5]. In a rule of law understanding, both rechtsstaats and the rule of law, the guarantee for human rights is an important part [6]. The guarantee of human rights becomes the spirit and soul of democracy as guaranteed by the 1945 Constitution.

One of the essential parts in the rule of law is the guarantee of human rights' protection. Therefore, the implementation of democracy must be based on legal values with respect for human rights as its primary basis. The principles of democracy and the rule of law should formulate the direct regional head election's main rules. The regulations for the Direct Regional Head Election must be clear and firm contains the principles of democracy and human rights, including those related to the requirement of the resignation of members of the House of Representative/local (DPR/DPRD) since being appointed as a pair of candidates in the election. Regulated in the Article 7 paragraph (2) alphabet s of Law Number 10 of 2016 concerning the Second Amendment above Law Number 1 of 2015 concerning Stipulation of Substitute Government Regulation to Law Number 1 of 2014 concerning The Election of the Governor, Regent and Mayor become a Law (hereinafter UU 10/2016).

Unfortunately, for some people, especially for the legislative members, this rule is considered unconstitutional. Due to not in line with the principles of legal certainty and legal justice because it ignores the constitutional right to get equal opportunities in government and the same benefits to achieve justice. Moreover, the concept of legislative's position members, including the House of Representative, Senate, Regional People's Representative Assembly, and the regional head, is a unity called 'political position ', as of the legislative member, who is wishing to run for the post of district head should not resigned from his post. As if it refers to the principle of justice and equality, it requires the same approach (equal treatment) for the same issue. Therefore, a person who is currently holding a political position should not a resign to run for another political office.

If we look at the context of justice in regional head candidacy, it should equate a legislative member's position with the incumbent. In fact, the incumbent has a higher potential to abuse his authority and power when he is re-nominated. But unfortunately, the law only makes it a mandatory rule to take a leave at the campaign time. There is one basis for comparing, and it is 'constitutional or unconstitutional' for the legislative member if they have to 'resign' from their position can be referenced with ministerial position that also called with the political position. But they should not be resigned when at the same time they put up their self in general or district head election [7].

The legal considerations of the Constitutional Court Decision Number 57/PUU-XI/2013, the reason for not requiring a ministerial position to resign is due to a ministerial position is a political position whose existence is very dependent on the President. It means that as long as the President requires the minister concerned can maintain it or vice versa [7]. Theoretically, the legal considerations align with legislative positions whose existence is bound and highly dependent on political parties.

Besides that, for legislative members, even though they do not resign, they do not have the mutatis mutandis to have more favorable position than other candidates. They can use their power for the benefit of winning because the principle of legislative power institution (legislative power) does not have a bureaucratic network that can draw as part of their winning strategy. Other than that, to run their authority, the legislative member can be detached from 
the conflict of interest and use of their position or power for the sake of winning, because as legislators, they do not carry out government functions or hold the budget.

This paper will answer whether the obligation to resign for the legislative members who wish to run for regional head has resulted in different treatment or not. The first part will discuss whether the resignation of the legislative members in the district head election has hindered the right to be elected or not. Meanwhile, in the second discussion will be explained whether there has been a different treatment (un-equal treatment) for legislators who want to run for regional heads? Before the conclusion, the explanation of whether it is necessary or no, to re-interpret the resignation of legislative members who contest the 2020 simultaneous regional head election will discuss.

\section{Has the Provisions for Resignation of Legislative Members in Regional Head Election Obstructed the Right to be Elected?}

For most legislators, the provisions of Article 7 Paragraph (2) Letter s of Law Number $10 / 2016$ considered having obstructed their constitutional rights, especially the right to be a candidate in the 2020 Regional Head Election. The cause is, they are required to resign from the position of a legislative member since being appointed as a candidate for election participants. However, if examined further, this provision does not diminish a person's right to participate in government. This provision does not preclude a person's right to run for regional head elections.

Because systematically, the provision begins with the provisions of Article 7 Paragraph (1) of Law Number 10/2016. It states that: "every citizen has the right to have the same opportunity to run for office and be nominated as a candidate for governor and candidate for deputy governor, candidate for regent and candidate for deputy regent, as well as candidates for mayor and candidate for deputy mayor". Thus, the provisions of Article 7 paragraph (2) letter s Law Number 10/2016 states that DPR/DPRD members who wish to run for regional heads must resign themselves first are the condition of an office where each occupation has specific requirements.

The Big Indonesian Dictionary (KBBI) defines 'Terms' as everything that is necessary or must exist (available, owned, etc.) [8]. Meanwhile, 'Position' is defined as a permanent job held for public interest [9]. According to Mariam Webster Dictionary, requirements are defined as something wanted or needed [10]. Furthermore, the position defined as social or official rank or status [11]. Thus, job requirements are everything that must be present/fulfilled by a person to accept for work (assignments) in an organization/institution.

Job requirements can also be interpreted as the minimum requirements that a person must fulfil to occupy a position to carry out his duties properly. A position has different requirements from other positions. When linked to the provisions of Article 7 Paragraph (2) of Law Number 10/2016, Candidates for Governor, Deputy Governor, Regent, Deputy Regent, as well as Mayor and Deputy Mayor must meet specific requirements. The provisions of Article 7 Paragraph (2) letter $\mathrm{s}$ in line with the requirements for members of DPR/DPRD. These are regulated in Article 240 Paragraph (1) Letter J of Law Number 7/2017 concerning General Elections (hereinafter the General Election Law), that DPR/DPRD members must work full time. It means that DPR/DPRD Members have understood from the start and are committed to working full time to carry out DPR/DPRD functions. 
The clause of resignation is not only regulated for the regional head nominee but also legislative members. It is held in Article 240 paragraph (1) letter k of the General Election Law that:

K. Resigning as District Heads, Deputy District Heads, Civil Servant, Members of the Indonesian National Army, Indonesian National Police Members, Directors, Commissioners, Supervisory Board, and Employees at BUMN and/or BUMD, or other Institution whose budgets come from state finances, which is stated by an irrevocable resignation letter

Furthermore, in the elucidation of the provisions of Article 240 paragraph (1) letter k of the General Election Law, it is stated that a letter of resignation cannot withdraw after the letter is received and followed up by the relevant agency. Regional heads, deputy regional heads, civil servants, members of the Indonesian national army, members of the Indonesian republic police, directors, commissioners, supervisory boards and employees of BUMN and/or BUMD, and other institution that have resigned to be legislative candidate candidates no longer have the status along with their rights and authorities since the person concerned is determined as a candidate in the final list of candidates.

Thus, it can mean that the requirements for resignation for members of the DPR/DPRD who determined as candidates in the district head election are not only a special obligation that applies to members of the DPR/DPRD, but also applies to other positions/professions. This resignation requirement does not prevent the applicants from participating in contesting the simultaneous regional head elections in 2020.

\section{Is There any Un-Equal Treatment for The Legislative Members Who Want to Run for Regional Heads?}

For the legislative members, the clause in Article 7 paragraph (2) letter s Law Number $10 / 2016$ had caused unequal treatment, as they were obliged to resign when they set as a candidate. According to the 60th Anniversary of adopting the Universal Declaration of Human Rights published in The Equal Rights Review, Volume 2 of 2008, define Equal treatment as an aspect of equality, is not equivalent to equal treatment. To realize full and effective equality, it is necessary to treat people differently according to their different circumstances, assert their equal worth, and enhance their capabilities to participate in society as equals [12].

The legislative members, the Head, and Deputy Head of a public office both elected by the people (elected officials). These public positions are different from those filled by appointment (appointed officials) just like the member of Indonesian National Army (TNI), Indonesian National Police (POLRI), Civil Servant (PNS/ASN), also the employees/officers at BUMN/BUMD. There is such a distinction due to the positions of House of Representative, Senate, and Regional People's Representative Council are political (political officials) obtained directly through the general election process by the people.

So that, the mechanism for resignation must also be caused by specific reasons as regulated in Law Number 17 of 2014 concerning the People's Consultative Assembly (MPPR), the House of Representative (DPR), the Senate (DPD), and the Regional People's Representative Council (DPRD). The positions of the TNI, POLRI, PNS/ASN, employees/officials in BUMN/BUMD are the professional profession and are career choices that must uphold neutrality. Thus, when a professional position was about to advance in the regional elections, it requires a retreat to maintain neutrality. 
Therefore, equality before the law guaranteed by Article 28D (1) of the 1945 Constitution does not mean to equate something different or differentiate something because it is equivalent to injustice.

Bagir Manan in the expert statement as quoted in Constitutional Court Decision Number 57/PUU-XI/2013 page 57 explains that:

There is an adage known to every lawyer who says, "Equalizing something different or not the same, equally unfair to distinguish the same." In the easy language, we can say that it is precisely a condition and way of realizing justice in particular circumstances distinguishing or unequal treatment. In some instances, making everything the same while being found that differences will also cause and hurt the sense of justice. If so, is there any objective requirement so that a difference or unequal becomes a condition for realizing justice? [13].

The same thing was also expressed by Laica Marzuki, that injustice (ungenrechtigkeit) distinguishes two things in common and equates two different things [13]. On this basis, it is theoretically equivalent arrangements regarding the resignation of candidates coming from members of the DPR, DPD, and DPRD (elected official) as well as candidates from the military, police, civil servants, employees/officials in the state or local government (appointed official).

Regulations regarding DPR/DPRD Members who are required to resign when appointed as a Regional Head or Deputy Regional Head in the Regional Head Election are not equivalent to incumbents who only leave outside the state's responsibility during the campaign period. Based on Law Number 5 of 2014 concerning State Civil Apparatus, Regional Head is a Civil Service Officer in the district. It is often to found some abusing plan to the authority of the Regional Head. They will run again in the elections when they use their positions to mobilize employees in the area to campaign and vote for that candidate. The DPR/DPRD members who are about to advance in the district head election do not have the authority to do so and are even required to resign from their positions, while those concerned have no mass and no territory.

In the implementation of the regional head election after enacting the provisions for the resignation of DPR/DPRD members. It can detrimental in terms of the loss of potential for mature candidates prepared by political parties, especially when faced with the condition that the incumbent does not have to retreat to benefit from the arrangement.

If we look closely, the implication of the existing and current regulation in Law Number $10 / 2016$ is favorable for incumbents who re-nominate in the same region. This arrangement is similar to the clause in Law Number 8/2015. In its application for the simultaneous district head election implementation on December 9, 2015, the incumbent regional head candidates who advanced in the 2015 election reached 82.5 per cent. Of these, 63.2 per cent majority of the incumbent or the contestation win [14]. Like the 2018 district head election, out of 171 electoral districts, at least 64 incumbent district heads prevailed and will lead the same region for the second time [15].

The arrangement resulting from the imperfection of the regulation in Article 7 paragraph (2) letter $\mathrm{p}$ of a quo Law that regulates the requirements for the incumbent to become a candidate that do not include arrangements for incumbents who re-nominate in the same regions have harmed incumbents who run in the other region with the incumbents who renominate in the same area. Due to this, the incumbent who was running back to the same area are most likely to get some benefit because it is hard to avoid the abuse of power/authority and make a climate of fair competition and equality (fairness) among the candidates for regional head and deputy's head area between incumbent and non-incumbent. 
Other than the clause is can't be applied to the incumbent, the clause in Article 7 paragraph (2) letter s of Law Number 10/2016 also can't be applied to the Ministerial Positions wishing to run for district head elections ministerial position is a political position just like the DPR/DPRD. However, ministers are not required to resign when running for the general election or district head elections (vide Constitutional Court Decision Number 57/PUU$\mathrm{XI} / 2013)$. The consideration [3.13] in Constitutional Court Decision Number 57/PUU$\mathrm{XI} / 2013$, become the basis of the clause above, said that:

[3.13] A ministerial position is a political position whose existence depends on the President. As long as the President requires the minister concerned, it can be defended or not ". These legal considerations are in line with "legislative positions" whose existence is bound and highly depends on the political parties" [7]

In terms of legal politics, legislators intend to prevent abuse of authority which can later benefit themselves and disadvantageous to others who are progressing in the Elections process in the same area. Apart from the misuse of authority, other things considered were the potential conflicts of interest and the use of the budget for his campaign either in the form of contributions or social assistance.

Meanwhile, if linked to the Constitutional Court Decision Number 33/PUU-XIII/2015, where the Court is of the view that both regional heads and deputy heads, civil servants, members of the TNI, and members of the National Police are positions that require resignation if they want to participate as candidates for legislative members, for different reasons. But the point is that these positions intersect with the authorities they carry, which are potential to be misused, resulting in reducing the fairness value in the general election that is to be participated in, and also potential to interfere with the performance of the position if the concerned did not resign.

Still, in the same section, the Court also emphasized that a civil servant or member of the TNI, a member of the National Police, or an official/employee of BUMN/BUMD who wants to run for district head or deputy district head must resign as a civil servant (or a member of the TNI, a member of the National Police, or BUMN/BUMD official/employee) after being officially appointed as a candidate for district head or deputy district head.

The Court's opinion is the right thing. Because that position is a career position that has received financial rights from the state and has planned as a state apparatus and a symbol of the state that present in the community must be neutral. But different from Members of DPR, DPRD, and DPD, their functions and duties are considered political offices.

Next, this article's existence also considered too caused legislative members unable to carry out their duties and authority and obligations for 5 (five) years because they were replaced by the Intertemporal Replacement (PAW) mechanism when competing in district elections. In the 2014-2019 period, at least 42 DPR members resigned because they wanted to participate in the district elections. This number is more than the turnover between times caused by criminal cases (corruption, etc.).

Based on 560 seats that constitute all seats in the DPR RI in the 2014-2019 period, as many as $22 \%$ of the DPR RI members are members of the inter-time substitution (PAW) most reason being to participate in the Regional Head Election. Based on the data above, if DPR/DPRD members are not required to resign since they appointed as candidates for the regional head, it will potentially disrupt the legislative institutions' functions (DPR, DPD, and DPRD).

Because the legislative position does not have a mechanism for ad-interim officials like acting legislator (Plt) or daily executors (Plh), suppose a legislative member becomes a regional head candidate. In that case, his duties as a legislative member become hampered, 
especially in essential policies, because the regional head candidates focus on optimizing the campaign period to socialize their programs to the public for 3-4 months. For incumbents, there is an obligatory instrument for leave office when carrying out a campaign. There are acting regional head (plt) and daily executors (plh) who will carry out the regional head's duties.
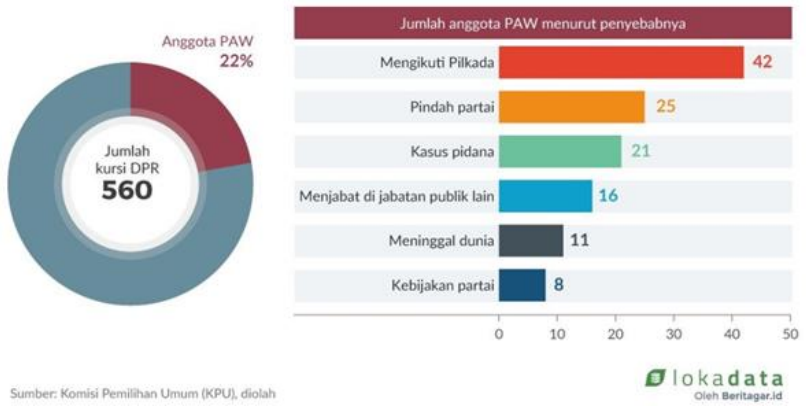

Fig 1. Number of DPR seats

The obligation to resign as a member of the legislature has presented a new paradigm for political parties that has accelerated the implementation of regeneration and recruitment of political parties to encourage new figures nominated as regional heads. This obligation has also ensured the legislative candidates to determine the direction of their dedication. If you become a legislative candidate, focus on carrying out duties full time. However, if you move to become a regional head candidate, the legislature's member must quit from a legislative member's position.

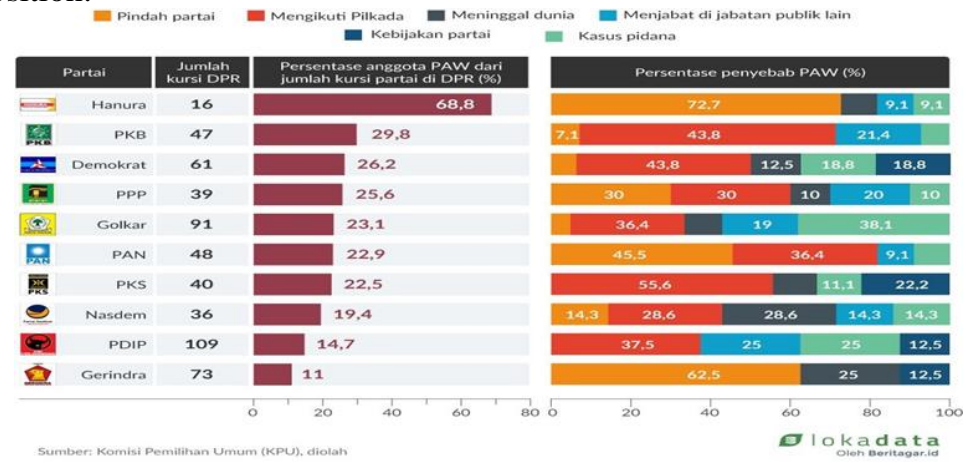

Fig 2. Percentage of PAW members

The obligation to resign for the legislative members was also in line and consistent with Indonesia's proportional legislative electoral system. When there is a legislative member who wants to run for the regional head, he/she must resign, and there will already be a replacement inter-time substitution (PAW), according to the most votes that will substitute him. The obligation to leave is also to ensure the legislative body's functioning continues. The representation function as a legislative member is also not disturbed because they are busy campaigning as candidates for the regional head.

Moreover, based on data released by the KPU, regarding the profession of regional head candidates in the 2020 Regional Head Election, there are 1 DPD member, 7 DPR members, 71 Provincial DPRD members, and 151 District/City DPRD members. So that with this large 
number, if not obliged to resign, it will certainly disturb the duties and obligations of those concerned as members of the legislative.

In terms of a comparative approach, in some democratic countries such as the United States, they have laws requiring officials who will run for general elections to resign from their positions even though they do not mention the Senate position. Meanwhile, there is the obligation to resign as a Senate or representative council member and civil servant in Australia.

However, if he fails in the election, he must regain his status as previously.

a. Australia

Australia has the Commonwealth Electoral Legislation Amendment Act 1983 that regulate everyone who nominates him as Prime Minister or nominates back as legislators must resign first from their membership as a member of the senate or house representatives or state civil apparatus. However, if he fails his election, he must regain his position as a member or previous status.

b. United State of America

In the state of Texas, according to Article 16, Section 65 (b) Constitution of Texas, only specific official position categories in the government of the state of Texas are required to resign from his work and publicly announced his candidacy. The details are as follows:

Sec. 65 Automatic Resignation on Becoming Candidate for Another Office.

a. This section applies to the following offices: District Clerks; County Clerks; County Judges; Judges of the County Courts at Law, County Criminal Courts, County Probate Courts and County Domestic Relations Courts; County Treasurers; Criminal District Attorneys; County Surveyors; County Commissioners; Justices of the Peace; Sheriffs; Assessors and Collectors of Taxes; District Attorneys; County Attorneys; Public Weighers; and Constables

b. if any of the officers named herein shall announce their candidacy, or shall in fact become a candidate, in any General, Special or Primary Election, for any office of profit or trust under the laws of this State or the United States other than the office then held, at any time when the unexpired term of office then held shall exceed one year and 30 days, such announcement or such candidacy shall constitute an automatic resignation of the office then held, and the vacancy thereby created shall be filled pursuant to law in the same manner as other vacancies for such office are filled.[17].

Interestingly, when Lyndon B. Johnson was elected Vice President in the United States elections in 1961, he also a member of the Senate for Texas's state representative. Lyndon B. Johnson did not resign as a member of the Senate first, and when elected as Vice President, then resigned from the Senate for the state of Texas. Likewise, in 2008, Barack Obama was elected President, and at that time, Obama was an active member of the Senate for the state of Illinois. After being elected President of the United States, then Obama resigned from the Senate seat.

The previous discussion explained that the nature of the position DPR/DPRD as political officials is different from Minister as political officials or incumbent as political officials. However, the legislative members should not change the article's meaning by applying a Constitutional Court petition. The action will cause unfair treatment (unequal treatment) to positions that must also resign when appointed as regional Head's candidate.

Moreover, the legislative institution does not have a bureaucratic network that can use as part of the campaign team. The legislative body is collective collegial so that it will not affect 
the authority of the legislative body. In this regard, the Court provides an opinion that office is a mandate that must be carried out and accounted for until the term-office is complete, both legislative officers, executive officers, and judicial officer are appointments to serve the people and creating people's welfare. They may hold carried out until the end of the term of office, whatever the position. So, if you can't complete your assignment by the end of your period, resigning is the best option to express the responsibility to the people. In decision Number 33/PUU-XIII/2015 dated 8 July 2015, the Constitutional Court has the following views:

The reason for legislators' (Government and DPR) is that DPR, DPD and DPRD are collectives collegial. So that if there are members of the DPR, DPD and DPRD running for regional heads or deputy regional heads they do not interfere with the implementation of their duties and functions, which is sufficient to serve as reasons for differentiating these responsibilities. Because people can immediately ask, what if the one running for regional head or deputy regional head is the DPR Leader, the DPD Leader, or the DPRD Leader, or even the DPR, DPD or DPRD official? Wouldn't that influence their duties and functions? If later elected, it will result in the re-election process to fill the vacant position that has been abandoned by the concerned. Thus, the problem is the crisis is collective collegial or not, but an issue of responsibility and mandate that the community has given to those concerned. [18]

\section{Is It Necessary to Re-interpret the Resignation Of DPR/DPRD Members Who Want to Run for the 2020 Regional Elections?}

In Case Number 22/PUU-XVIII/2020, the Petitioners, especially legislative members, ask the Court to transform its opinion of the meaning of obligation to resign when run in the simultaneous regional elections 2020. According to the Petitioners, the Court can change its view as in the previous decision was due to the provisions of Article 7 paragraph (2) letter s of Law 10/2016, which contradicts Article 27 Paragraph (1), Article 28D Paragraph (3), and Article 28H Paragraph (2) of the 1945 Constitution. The Petitioners also gave an example that the Court has changed its opinion several times. The Constitutional Court Decision regarding the time limit for the publication of quick counts, the Constitutional Court Decision regarding the Presidential and Legislative Elections in line, and the decision regarding former prisoners' requirements to run for election.

According to Gennaioli and Andrei Shleifer in an article entitled Overruling, and the Instability of Law, shifting a judicial position that differs from the previous judicial position in seeking constitutional truth is called overruling [19]. The nature of overruling emphasizes the essential point that a court can provide an opinion that is different from the previous Court's opinion with its new judicial considerations.

In principle, the practice of overruling is legitimate as long as it aimed at pursuing constitutional truth in the context of constitutional interpretation. That is, legally, sociologically, and morally, the Court is required to provide the correct interpretation.

a. Legal Legitimacy

When the Constitutional Court exercised its authority in examining laws, the correctness of constitutional interpretations was very substantial because the misinterpretation of the constitution was an unconstitutional practice of constitutional change. Therefore, the constitution is the standard for the accuracy of its interpretation [20]. 


\section{b. Sociological Legitimacy}

Sociological legitimacy is based on factual acceptance from society. For example, the Decision of the Constitutional Court Number 25 / PUU-XIV / 2016 states "there is a fundamental reason for the Constitutional Court to change the constitutionality assessment of the previous decision because the previous decision repeatedly caused legal uncertainty and injustice in the eradication of corruption". This decision shows that there are corrective actions against previous decisions deemed to deviate from the constitution's truth. This overruling practice is always justified by society if it desires to seek the constitution's truth [20].

c. Moral Legitimacy

The practice of overruling is considering morally valid if the judge is motivated to produce correct constitutional interpretations and at the same time, make corrections to previous interpretations. So, the judge is obliged to state the valid law [20]. In this moral legitimacy, the decision making whether to follow the previous Court's opinion or whether it was different from the previous Court's opinion was utterly dependent on the judge.

The question is, there are new conditions that make the Court need to review its Constitutional Interpretation? If traced, the Petitioner's norms have been requested for testing and have been decided by the Court in Decision Number 45/PUU-XV/2017 dated 28 November 2017, and Number 64/PUU-XV/2017 dated 14 December 2017, with the decision 'Rejecting all of the Petitioners' Applications'. The Court's reason for rejecting the petition was because of the norms contained in Article 7 paragraph (2) letter s of Law 10/2016 following Decision Number 33/PUU-XIII/2015. The Court also confirmed that the Constitutional Court's stance as stated in the Decision Number 33/PUU-XIII/2015 is also an affirmation of the previous Court's opinion, as stated in the Decision Number 41/PUU-XII 2014 [21].

In Decision Number 64/PUU-XV/2017, the Court emphasized that the Court did not find any changes that caused the Court to change its stance, especially to provide a new constitutional interpretation of a quo norm [21]. One of the reasons that may differ from this petition is to ask the Court to state that Article 7 paragraph (2) letter s of the Law on Regional Head Elections is conditionally unconstitutional unless it interprets as 'resigning from the position of the board member since being appointed as a candidate'. Therefore, there is no fundamental reason for the Court to change its opinion.

According to Bivitri Susanti, an expert presented by the Related Party, namely association for elections and democracy (Perkumpulan untuk Pemilu dan Demokrasi/Perludem), said that the Constitutional Court had consistently decided 5 (five) previous decisions regarding the obligation to resign after being appointed as a candidate for the regional head. This obligation applies to every civil servant, member of the TNI/Polri, including members of the DPR, DPD and DPRD appointed as candidates for the regional head. If the Court will change the stance of the five existing decisions, there must be other conditions that change drastically, which require the Court to change its opinion and conclusion. Furthermore, there have been no significant changes in the political, economic, or sociological situation since the Court decided on a similar case in 2015. Likewise, there has been no change in the legal framework, which requires changes in a quo article to be harmonized.

Titi Angrraini as an expert on related parties Perludem also conveyed the same thing, if it is associated with the parliament's institutional nature in the Indonesian constitution designed so that the elected DPR members, DPD, and DPRD can work full time. This design is in line with their duties, powers and functions with all the facilities and compensation given to them. 
The construction of a full-time parliament is coherent with Indonesia's electoral system which implements an open-list proportional system. The electoral district's allocation is 3-10 seats for the DPR RI and 3-12 seats for the DPRD, with a quota of up to $100 \%$ of the contested seats. This arrangement makes political parties have sufficient or arguably excess stock to fill essential positions in the parliament to work optimally and full time in carrying out their crucial role as representatives of the people.

So that if there are elected DPR and DPRD members who want to run for other political positions through the Regional Head Election, then there is an Interim Replacement Mechanism (PAW) can apply that. The same scheme also applies to DPD members who will run to the regional head election.

\section{Conclusion}

The obligation to resign for DPR/DPRD members who have been appointed as candidates in regional elections is not only for DPR/DPRD members, but also for other positions/professions such as Civil Servants, TNI/POLRI, and BUMN/BUMD. This resignation does not prevent the applicants from participating in the 2020 regional head elections. Although by nature, the position of 'DPR / DPRD as a political office' is treated differently from Minister as a political office or incumbent as a political office. However, if this petition granted, it needs to be emphasized that it can lead to unequal treatment of other positions that must also resign when appointed as candidates for election.

The obligation to resign as a member of the legislature has presented a new paradigm for political parties, to accelerate the regeneration and recruitment of political parties and encourage new figures to nominate as regional heads. This obligation has also ensured the legislative candidates to determine the direction of their dedication. If you become a legislative candidate, focus on carrying out duties full time. However, if you move to become a regional head candidate, the legislature's member must quit from a legislative member's position.

The obligation to resign for the legislature members is also in line and consistent with Indonesia's proportional legislative electoral system. When there is a legislative member who wants to run for the regional head, he/she must resign, and there will already be a replacement candidate between times, according to the most votes that will replace him. It will also ensure that the legislative body's function continues. The role of representation as a council member is not disturbed because legislative members are busy campaigning as candidates for the regional head.

Besides, currently, there are no circumstances that cause the Court to change its stance, let alone to provide a new constitutional interpretation of the norms of Article 7 paragraph (2) letters of Law 10/2016. The Constitutional Court has consistently decided 5 (five) previous decisions regarding the obligation to resign after being appointed as a pair of candidates for each civil servant, TNI / Polri member, DPR, DPD, and DPRD members. They were selected as candidate pairs for the regional head. If the Court is to change the five existing decisions' stance, other conditions must change drastically, which compel the Court to change its view. Moreover, there have been no significant political, economic, or sociological changes since the Court ruled a similar case in 2015. Likewise, there has been no change in the legal framework, which requires changes in the quo article to be synchronized. 


\section{Acknowledgements}

The author[s] would like to thank the Center for Research and case Analysis, the Constitutional Court of the Republic of Indonesia for providing support both morally and materially.

\section{References}

[1] Hanafi, R. I.: Pemilihan Langsung Kepala Daerah Di Indonesia: Beberapa Catatan Kritis Untuk Partai Politik, Jurnal Penelitian Politik, Vol 11, No 2, pp. 1-16 (2014)

[2] Marijan, K.: Sistem Politik Indonesia: Konsolidasi Demokrasi Pasca-Orde Baru, pp. 83. Kencana Prenada Media Group, Jakarta (2010()

[3] Hirst P., and Khilnani, S. (Eds.).: Reinventing Democracy, pp. 39. Blackwell Publishers, Cambridge (1996)

[4] Zuhro, R. S., et.al.: Model Demokrasi Lokal, pp. 23-24. PT. THC Mandiri, Jakarta (2011)

[5] Ghafur, J., and Wardana, A. F. G.: Problematika Pengaturan Cuti Kampanye Kepala Daerah Incumbent Dalam Pemilihan Kepala Daerah Dan Wakil Kepala Daerah Di Indonesia, Jurnal Novelty, Vol 8, No 1, pp. 70-90 (2017)

[6] Aditya, Z. F.: Asas retroaktif Putusan Mahkamah Konstitusi dalam Teori dan Praktik, pp.

[7] 66. Rajawali Press, Jakarta (2020)

[8] Indonesian Constitutional Court Decision Number 57/PUU-XI/2013

[9] https://kbbi.kemdikbud.go.id/entri/syarat also see Poerwasunata, WJS.: Kamus Bahasa Indonesia Edisi Ketiga, Balai Pustaka, Jakarta (2003)

[10] Utrecht, E.: Pengantar Hukum Tata Usaha Negara Indonesia, pp. 144. NV Bali Buku Indonesia, Jakarta (1957)

[11] https://www.merriam-webster.com/dictionary/requirements

[12] https://www.merriam-webster.com/dictionary/position

[13] The 60th anniversary of the adoption of the Universal Declaration of Human Rights, The Equal Rights Review, Vol 2, (2008)

[14] Indonesian Constitutional Court Decision Number 1/PUU-X/2012, pp. 57. [14]

[15] https://www.beritasatu.com/anselmus-bata/nasional/344756/632-petahana-menangi-pilkada [15]

[16] https://nasional.kompas.com/read/2018/07/26/18520301/64-kepala-daerah-petahana-terpilih-p adapilkada-serentak-2018?page=all

[17] Article 16 Section 65(b) Constitution of Texas

[18] Indonesian Constitutional Court Decision Number 33/PUU-XIII/2015

[19] Gennaioli, N., and Shleifer, A.: Overulling and the Instability of Law, Journal of Comparative Economic, Vol. 35, pp. 309 (2007)

[20] Rauta, U., et.al.: legitimasi Praktik Overulling di Mahkamah Konstitusi, Hasil Penelitian Kompetitif Kerjasama Mahkamah Konstitusi dengan Fakultas Hukum Universitas Kristen

[21] Satya Wacana Tahun 2018.

[22] Indonesian Constitutional Court Decision Number 64/PUU-XV/2017, pp. 48-19. 